\title{
Research on Strengthening Precision Investment Management Ability of State-owned Enterprises
}

\author{
Qian Zhang ${ }^{1 *}$, Jiaxu Cheng ${ }^{1}$ and Yuxi Zhang ${ }^{2}$ \\ ${ }^{1}$ State Grid Energy Research Institute Company Limited, Beijing, 102209, China \\ ${ }^{2}$ China Electric Power Research Institute Co., LTD. Beijing 100192, China \\ Email of all the authors: zhangqian881111@163.com; chengjiaxu@sgeri.sgcc.com.cn; zhangyuxi@epri.sgcc.com.cn \\ *Corresponding Author: Zhang Qian; zhangqian881111@163.com; 18810316307; 010-66603486
}

\begin{abstract}
Investment management is an important operation and management activity for enterprises. Unreasonable investment will bring huge losses to the enterprises. Therefore, it has attracted the attention of the regulatory authorities and all sectors of society. Especially for state-owned enterprises, investment is generally strategic and major economic activities that lead the development of the industry. The investment projects are huge and last for a long time. The payment and recovery of funds have a great influence on the working capital of enterprises. This paper focuses on the future investment supervision trend, analyzes the current situation of investment management of state-owned enterprises, and puts forward relevant suggestions on improving the precision investment ability of state-owned enterprises based on the practical experience of domestic advanced enterprises.
\end{abstract}

Keywords: Investment management; investment supervision; state-owned enterprises.

\section{INTRODUCTION}

From the perspective of the scale and efficiency of state-owned enterprises, by the end of 2020, the total assets of enterprises supervised by the state-owned assets system had reached 218.3 trillion yuan, the operating income in had reached 59.5 trillion yuan, and the total profits had reached 3.5 trillion yuan. The average annual growth rates during the 13th Five-Year Plan period were $12.7 \%, 7.4 \%$ and $10.7 \%$, respectively. The total assets of central enterprises have continuously exceeded 50 trillion and 60 trillion marks, reaching 69.1 trillion at the end of 2020 , with an average annual growth rate of $7.7 \%$. However, the overall annual return rate of state-owned enterprises is less than 5\%. The problems of large but not superior are prominent for state-owned enterprises. Therefore, for state-owned enterprises, strengthening investment management, ensuring the preservation and appreciation of state-owned assets, and obtaining a sustained and stable source of income, are the primary tasks to solve the low return on net assets.

\section{FUTURE INVESTMENT REGULATORY REFORM TRENDS}

From the great task of deepening the reform of state- owned assets management system put forward by the 18th National Congress of the Communist Party of China to the great deployment made by General Secretary Xi Jinping at the 19th National Congress to improve the state-owned assets management system and deepen the reform of state-owned enterprises, state-owned enterprises have gone through a process of continuous improvement of corporate governance mechanism, and the state-owned assets supervision system has been optimized and improved accordingly[1].

Investment supervision, as an important part of stateowned assets supervision and reform of state-owned enterprises, is based on the establishment and improvement of internal investment decision-making mechanism. Investment supervision is constantly adjusted and optimized with the new problems in practice. Focusing on the development process of investment supervision reform, the key directions of investment supervision of state-owned enterprises in the future can be summarized into the following three aspects.

First, state-owned enterprises should focus on guiding the investment direction, so that investment can help fulfill their responsibilities. State-owned enterprises are the important material and political foundation of socialism with Chinese characteristics. By strengthening 
investment supervision and making clear the key development areas and investment directions of enterprises. Truly, at the critical moment when the party and the people need it, they can draw, meet, stand and win, and play the positive role of the "pillar" of the socialist economy. Restricting the investment direction of enterprises is the top priority of investment supervision. When the layout of state-owned capital is optimized and controlled, the investment supervision will stabilize the premise and occupy the commanding heights[2].

Second, pay attention to the prevention and control of investment risks by improving the selection and employment mechanism and internal decision-making mechanism of enterprises. From practical experience, the losses caused by improper investment are not only affected by external environment such as macroeconomy, industrial development and market development, but also related to the imperfect internal decision-making mechanism of enterprises and the ineffective corporate governance mechanism. Collective decision-making can't play a role[3]. Therefore, the future investment supervision of state-owned enterprises will pay attention to the construction of modern enterprise system with Chinese characteristics, strengthen the role of party organizations in internal decision-making, implement the decision-making mechanism of "three majors and one big", rationally divide the power boundaries of party committees, board of directors, board of supervisors and managers, and urge enterprises to improve the decision-making mechanism. To realize the effective checks and balances of various power institutions within the enterprise.

The third is to improve the efficiency and level of investment supervision by improving the management and post-evaluation of investment events. Vigorously promote the follow-up investment mechanism, improve the incentive mechanism, and deeply bind the interests of shareholders and the interests of internal investment decision makers, stimulate the business wisdom of enterprise decision-making and management, and improve the efficiency of investment supervision[4]. Strengthen project process supervision, encourage timely stop loss and establish institutional arrangements for investment correction and correction. Do a good job in post-project evaluation, implement accountability for investment mistakes, and take a three-pronged approach of responsibility, right and benefit, which cannot be neglected.

\section{STATUS QUO OF INVESTMENT MANAGEMENT In STATE-OWNED ENTERPRISES}

Combined with the development direction and key points of investment supervision of state-owned enterprises in the future, this section combs and summarizes the present situation of investment management of state-owned enterprises by means of investigation, interview and literature research.

First, there is a lack of effective evaluation of the investment budget quota, and the scientific and precise investment decisions need to be further improved. Because of the particularity of state-owned enterprises, they have the management nature of "planning", which requires them to make good decisions in advance to promote the investable budget quota for enterprise development in the next year. But in the actual operation process, When some state-owned enterprises don't specify the investment projects, they also need to specify the investment quota and determine the investment scale in advance to ensure the utilization rate of funds. Excessive pursuit of "planning" has caused some stateowned enterprises to rely on experience and simply rely on economic benefit indicators to predict investment scale in the process of investment decisionmaking.Investment decision-making is not practical and scientific, which makes it difficult to respond to market demand quickly. This situation is a difficult problem for state-owned enterprises, and will also have an impact on their future development[5].

Second, the coordination of various departments in the investment management process is not high, the management chain is long, and there are many decisionmaking links. The departments of state-owned enterprises are generally complex and have many levels. In the process of project investment management, many departments are often required to participate, which is manifested in the long decision-making chain. Many examination and approval links and slow response speed of state-owned enterprises. To a certain extent, it restricts the competitive power and efficiency of state-owned enterprises.

Third, the investment effectiveness is not paid enough attention, and a closed-loop evaluation mechanism is not formed. At present, some state-owned enterprises do not pay enough attention to the investment effect, and the investment arrangement lacks operational decisionmaking analysis support tools. It is necessary to further study the input-output situation of various projects of enterprises and classify and evaluate the input effect of each project. Constantly accumulate experience for input decision-making.

Fourth, the investment management system needs to be further improved. Most of the decision-making management of investment projects in state-owned enterprises has the phenomenon of "putting emphasis on the former and neglecting the latter", that is, paying attention to the evaluation and investigation before investment, writing the feasibility report and reporting to the higher authorities, ignoring the supervision and supervision of the follow-up operation and management of investment projects. The investment management system is not perfect, There is no specific supervision and 
regulation clause, especially the effective safe exit clause, which increases the risk coefficient of the invested funds.

\section{PRACTICAL EXPERIENCE}

\subsection{State Grid Corporation}

With the continuous promotion of power system reform and the reform of state-owned enterprises, State Grid Corporation has done a lot of work to improve the accuracy of its investment management by constantly exploring practice and innovating institutional mechanisms. The management and control ability of enterprises has been continuously enhanced, which has played an important role in promoting the high-quality development of enterprises.

First, focus on the main internal and external situations faced by enterprise investment management, and clarify the main optimization and improvement direction of enterprise investment management under the new situation. In order to adapt to the new situation of reform and development and implement the company's new development strategy, State Grid Corporation has defined the new theoretical connotation and development direction of enterprise investment management, that is, to fully implement the development strategy and planning in the new era.Support the new development layout, foster new development momentum, stimulate new vitality of management, continuously improve energy resources and the Group's resource allocation capacity, give full play to the leading role of overall planning, focus on safety, efficiency and efficiency, ensure the healthy development of the power grid and new industries of industry and finance, achieve the best overall benefits of the company and promote the highquality development of the power grid and the company.

Second, focusing on the principle of efficiency and benefit, implementing the concept of lean management and precise investment, and putting forward a simplified scheme of investment management process. In order to adapt to the new situation, State Grid Corporation further optimized and improved the investment management process. Simplify the project reserve process, improve the audit efficiency, implement the annual normal demonstration reserve of the project, and ensure the timely demonstration and timely implementation of various needs. Establish a green channel mechanism for new projects. During the implementation of the annual plan, the unplanned new projects such as power grid emergency and unified decision-making supplement will be balanced within the planned scale by each unit. If it is really necessary to supplement the planned scale, it must be reported to the headquarters for implementation after fulfilling the procedures and incorporated into the plan adjustment. To carry out project association demonstration, in order to avoid repeated investment and improve project execution efficiency, Give full play to the overall benefits of the project simultaneously. For different projects with electrical connections or functional targets within and between special projects, carry out demonstration of related benefits within and across special projects, and form multi-level project clusters across special projects, so as to ensure that related projects are put into production synchronously and bring into full play the overall benefits in time[6].

Third, build a scientific model to predict the scale of investment, and formulate investment strategies scientifically and reasonably. In order to implement the evaluation index of "two benefits and four rates" of central enterprises' operating performance in 2020 and the relevant requirements of power system reform, the constraints such as planning investment, nuclear price investment and investment ability are considered in an overall way, and the influence of supply and demand and macro and micro environment on enterprise resource input is combined. The index system that affects the total investment scale of the company is constructed from the aspects of external index, power grid scale and quality index, enterprise operation index, etc. The index data is used to regress and calculate the total investment scale of the enterprise resources, which provides decision-making basis for the determination of investment scale.

Tab 1. The index system of investment forecast

\begin{tabular}{|c|c|}
\hline $\begin{array}{l}\text { First level } \\
\text { indicators }\end{array}$ & Secondary indicators \\
\hline \multirow{8}{*}{$\begin{array}{l}\text { Management } \\
\text { benefits }\end{array}$} & Electricity Sales \\
\hline & Line loss rate \\
\hline & Operating income \\
\hline & Total profit \\
\hline & Total assets \\
\hline & Assets and liabilities \\
\hline & Controllable expenses \\
\hline & Economic value added \\
\hline \multirow{6}{*}{$\begin{array}{l}\text { Operation } \\
\text { efficiency }\end{array}$} & New energy consumption rate \\
\hline & Return on Equity (Roe) \\
\hline & Electricity receivable balance \\
\hline & $\begin{array}{l}\text { Electricity fee recovery rate for the } \\
\text { year }\end{array}$ \\
\hline & Number of employees \\
\hline & Overall labor productivity \\
\hline \multirow{6}{*}{$\begin{array}{l}\text { Customer } \\
\text { service }\end{array}$} & Grid frequency qualification rate \\
\hline & City power supply reliability rate \\
\hline & Rural power supply reliability rate \\
\hline & $\begin{array}{l}\text { Comprehensive power supply } \\
\text { voltage qualification rate of urban } \\
\text { power grid }\end{array}$ \\
\hline & $\begin{array}{l}\text { Comprehensive power supply } \\
\text { voltage qualification rate of rural } \\
\text { power grid }\end{array}$ \\
\hline & $\begin{array}{l}\text { Business expansion service time } \\
\text { limit compliance rate }\end{array}$ \\
\hline
\end{tabular}

Development speed of investment $(\mathrm{t})=\mathrm{F}$ (Development speed of investment $(\mathrm{t}-1)$, development speed of influencing indicators(t-1)). 
The performance evaluation adjustment coefficient $=$ $\left(\frac{S 1_{t}}{S 1_{t-1}}\right)^{\alpha}\left(\frac{S 2_{t}}{S 2_{t-1}}\right)^{1-\alpha}$

Where The comprehensive plan execution score $S 1$ is calculated according to the comprehensive plan index system, and the input-output score $S 2$ is calculated according to the input-output evaluation system. The performance evaluation adjustment coefficient is the weighted geometric average of the chain value of scores.

Where, $0 \leq \alpha \leq 1, \alpha$ is used to adjust the weight of two performance evaluation results.

The total investment $=$ Development speed of investment $(\mathrm{t})^{*}\left(\frac{s 1_{t}}{s 1_{t-1}}\right)^{\alpha}\left(\frac{s 2_{t}}{s 2_{t-1}}\right)^{1-\alpha}$

\subsection{China National Offshore Oil Corporation}

In order to adapt to the complex and changeable internal and external environment changes, CNOOC began to implement the centralized management reform of oil companies in 1993, and standardized the budget and investment decision-making behavior of oil companies, realized centralized and unified management of relevant decisions, improved the scientific nature of decisions, and provided institutional guarantee for the rapid development of oil companies[7].

First, an all-round investment supervision system has been established to strengthen investment management risk supervision. In order to solve the "blind area" difficult to cover in traditional supervision methods, CNOOC has established a "five-in-one" supervision system-inner-party supervision, audit supervision, discipline inspection supervision, board of supervisors and management departments[8]. Combine with the modern corporate governance mechanism to implement the coordination within the supervision function. In the inner-party supervision, CNOOC's "red line culture" transforms the party's discipline style into executive power and clarifies the bottom line of employees' behavior. At the same time, Through the responsibility assessment and investigation system of "four hooks and one veto" (audit supervision, discipline inspection supervision, supervision by supervisors, supervision by management departments and two-way voting system), the leaders and managers at all levels have become the main body of the responsibility system for building a clean and honest government.

Four hooks and one veto

\begin{tabular}{|c|c|c|c|c|}
\hline in & $\square$ & - & P & $\cdots$ \\
\hline Audit supervision & $\begin{array}{l}\text { Discipline inspection } \\
\text { and supervision }\end{array}$ & $\begin{array}{c}\text { Supervised by Board } \\
\text { of Supervisors }\end{array}$ & $\begin{array}{l}\text { Management } \\
\text { supervision }\end{array}$ & $\begin{array}{c}\text { Two-way voting } \\
\text { system }\end{array}$ \\
\hline $\begin{array}{l}\text { Supervise and } \\
\text { monitor the safety of } \\
\text { enterprise assets, } \\
\text { resource utilization } \\
\text { efficiency and business } \\
\text { risks, and constantly put } \\
\text { forward suggestions for } \\
\text { improvement. } \\
\text { - Rely on social forces } \\
\text { to strengthen audit } \\
\text { supervision to prevent } \\
\text { risks and reduce } \\
\text { supervision costs. }\end{array}$ & $\begin{array}{l}\text { By establishing a sound } \\
\text { punishment system, carrying } \\
\text { out various specific businesses } \\
\text { according to the deployment } \\
\text { and management authority, } \\
\text { enhancing the integrity } \\
\text { awareness of enterprise } \\
\text { m an a g e ment cadres, } \\
\text { promoting the steady progress } \\
\text { of clean government } \\
\text { construction and discipline } \\
\text { inspection and supervision, } \\
\text { and providing guarantee for } \\
\text { risk management. }\end{array}$ & $\begin{array}{l}\text { Full-time staff should be } \\
\text { supervisors to strengthen } \\
\text { supervision over important } \\
\text { subsidiaries. }\end{array}$ & $\begin{array}{l}\text { Revise the agenda of the } \\
\text { management committee } \\
\text { and investment decision- } \\
\text { making com mitte e, } \\
\text { including the agenda of the } \\
\text { party group, and clarify the } \\
\text { agenda of the three major } \\
\text { organizations. }\end{array}$ & $\begin{array}{l}\text { - The principal responsible } \\
\text { person agrees and more than } \\
\text { two-thirds of the members } \\
\text { disagree, so investment } \\
\text { cannot be made; If more than } \\
2 / 3 \text { of the members agree but } \\
\text { the principal responsible } \\
\text { person dis a grees, no } \\
\text { investment can be made. } \\
\text { - Promote democratic } \\
\text { centralized management and } \\
\text { supervision, and make } \\
\text { decisions on major } \\
\text { investment projects to } \\
\text { prevent possible risks. }\end{array}$ \\
\hline
\end{tabular}

Fig. 1 CNOOC's responsibility assessment and investigation system of "four hooks and one veto"

Second, the centralized management of budget and investment decisions should be implemented, and the scientific and precise investment decisions should be continuously strengthened. CNOOC has continuously revised and improved the whole budget and investment decision management system. All investment projects are required to be "demonstrated first, then decided".In the process of project establishment, feasibility study and basic design (preliminary design), four basic principles must be adhered to: economic benefit first, scientific and democratic decision-making, handling affairs according to procedures and responsible person system, among which economic benefit first is the primary consideration factor in investment decision-making.

The third is to strengthen the market-oriented value creation system and continuously improve the company's resource allocation ability[9]. Seriously handle the relationship between coordinated development and market-oriented operation, optimize the allocation of crude oil and refined oil resources and adjust the investment structure, and promote the overall upgrading and efficiency improvement of products according to the development principle of "controlling the total amount, adjusting the structure and making up the shortcomings". Gradually make the market become the most important means of China's offshore oil resources allocation. 


\subsection{China Huaneng Group Co., Ltd.}

In order to improve the efficiency and benefit of enterprise resource allocation, Huaneng Group adjusted its investment strategy in time, defined its resource allocation process, and established a complete and effective fund management system and process, which greatly promoted the efficiency and level of decisionmaking in resource allocation.

First, adjust the investment strategy in time according to the changes of internal and external environment. In the process of project investment, Huaneng Group fully considers the restriction of internal and external environmental factors, and appropriately adjusts the investment proportion of different types of projects according to the change of environment. With the national Work Plan for Strengthening Air Pollution Prevention and Control in Energy Industry, Action Plan for Upgrading and Reconstruction of Coal-fired Power Energy Saving and Emission Reduction (2014-2020), Target and Task for Upgrading and Reconstruction of Coal-fired Power Saving and Emission Reduction in Central Power Generation Enterprises in 2015 and the new Environmental Protection Law being put in place gradually, the national standards in the field of energy saving and environmental protection are becoming increasingly strict. The environmental protection requirements of energy development are constantly improving, and the cost of newly installed and modified units is further increased. Under such internal and external environmental pressure, Huaneng Group increased its investment in technological transformation, reaching $17.64 \%$ of the total capital expenditure. Investment in coal-fired power projects continued to shrink to $11.78 \%$. As 2019 is the last year of the adjustment cycle of wind power on-grid tariff,Wind power subsidies will be cancelled after 2020 , so 2019 2020 is the last big cycle of wind power rush. In order to adapt to the changing situation, in 2019, the investment in wind power projects of Huaneng Group reached 67.64\% of the total capital expenditure.

Second, increase investment in green development in line with the needs of strategic transformation. In recent years, Huaneng Group has increased its investment in thermal power treatment in order to cope with the strategic transformation. The total investment in thermal power low-carbon treatment has exceeded 100 billion yuan, and many projects have achieved remarkable results. Huaneng Group has increased desulfurization and emission reduction devices for outsourced thermal power units. On the basis of supercritical unit technology, Construction of ultra-supercritical units, in which Tianjin IGCC Power Station has made a major breakthrough in coal-fired power technology. A series of achievements have proved that Huaneng Group has made good gains in resource allocation in technology investment, making low-carbon thermal power technology come to the forefront of the industry.

Third, implement the responsibilities of management institutions and clarify the investment management process. Huaneng Group adheres to the principle of excellent performance and leading the industry in resource allocation. Taking the comprehensive plan as the main starting point to guide the allocation of resources for the overall development of the company, all professional plans are incorporated into the comprehensive plan of the company for unified management.Achieve unified preparation, unified reporting, unified release and unified adjustment. At the same time, Huaneng Group's annual plan formulation will comprehensively consider the internal and external environment of the company's development, take into account the development needs and development capabilities, allocate resources as a whole, optimize the balance, and strive to fill shortcomings, control risks, and ensure the coordination and unity of safety, quality, scale and efficiency. In addition,Huaneng Group has established a complete and effective fund management system and process, which has greatly promoted the efficiency and level of decision-making in resource allocation.

\section{CONCLUSION}

(1) Strengthen the study of national policies and market demand, make full use of internal and external data, and improve the scientific and rational allocation of resources.

Investment decision-making management of stateowned enterprises should not only ensure the profits of enterprises, but also play the guiding role of government policies to achieve high-quality economic development. For state-owned enterprises, first, they should fully fulfill the requirements of government supervision and user service, and bring government demands, key customer needs and regional economic development into the process of measuring the investment scale of enterprises.So as to promote the coordinated development of enterprise management and regional economy and improve the profitability of enterprises; The second is to increase investment in the research and development of new technologies, continuously upgrade technologies, optimize the business environment, and increase the market share of enterprises, thus bringing about an improvement in efficiency; Third, strengthen internal and external data accumulation, improve data quality,Scientific analysis of enterprise investment scale, structure and allocation mode, prediction of regional economic development trend and market demand trend, provide data support for enterprise resource allocation, and improve the scientific and rational decision-making.

(2) Improve the investment management system and strengthen the supervision of investment projects. 
First, improve the investment management system, refine the various steps of investment management, especially set detailed supervision and supervision clauses and effective and feasible safe exit clauses, clarify the division of responsibilities on the follow-up management of investment projects, set up special departments, and designate professional supervisors to connect with enterprises; Second, actively promote the adjustment of performance appraisal methods.From the aspects of enterprise's current scale, business development status and future development direction, the enterprise's asset investment management can be gradually transformed into comprehensive assessment before, during and after the event, and an investment evaluation mechanism with clear responsibilities and equal rights and responsibilities can be established to ensure the project implementation effect.

(3) Optimize the investment structure and formulate the investment strategy reasonably.

Decision-making managers of state-owned enterprises must regularly sort out, scientifically classify and uniformly allocate all investment projects, take effective measures, integrate enterprise resources, and give full play to the role of investment activities in adding value and increasing efficiency for enterprises. First, appropriately relax the examination and approval authority of the project, optimize the resource allocation of the investment structure, and thus reduce the probability of investment risks.Simplify the procedures and processes of examination and approval, and put the feasibility project research report into the examination and approval content, so that investors can have a clearer understanding of investment projects; The second is to explore diversified investment portfolio methods, increase the flexibility and operability of investment, realize the optimal allocation of enterprise resources, guard against investment risks and minimize investment deviation.

(4) Strengthen the construction of investment talents.

While strengthening asset investment management, state-owned enterprises also need to pay attention to the construction of investment talents. At the present stage, the construction of investment talent team and related mechanisms should be put in the first place. Only by perfecting the investment talent team system can the investment management level be effectively improved.First, in the process of building the investment talent team, state-owned enterprises should take business as the basic core, sort out the management structure and related processes, and make each work tend to be optimized; The second is to build a team of investment talents with high comprehensive quality and strong investment management ability, so as to improve work efficiency and enhance the value of enterprise assets.

\section{REFERENCES}

[1] Li M., Li X. D. Research on Investment Allocation Model of Power Grid Based on Investment Capability $[\mathrm{J}]$. Northeast Electric Power Technology, 2016 37(1), pp. 19-23.

[2] Sha M. Y., Chen S. Y., Gao M. G., et al.. Research on the Investment Allocation of Comprehensive Plan of Power Grid Enterprises under the Electricity Transmission and Distribution Price Reformation [C]. 2nd International Symposium on Resource Exploration and Environmental Science, 2018.

[3] M Y. Z., He W., Ma Y. G. Research on Power Grid's Investment Strategy Based on the Improved Development Stage Decision Model of Power Grid [C]. Conference Proceedings of the 6th International Symposium on Project Management, 2018.

[4] Qu X. G., Cui G.Z., Sun G., et al.. Analysis on the whole process management of integrated plan of power supply enterprises [J]. Modern Commerce and Industry, 2016, 37(22), pp. 83-84.

[5] Asker J., Farre-Mensa J., Ljungqvist A. Corporate Investment and Stock Market Listing: A Puzzle? [J]. Review of Financial Studies, 2015, 28(2), pp. 342-390.

[6] Ali Haider Z. Government ownership, financial constraint, corruption, and corporate performance: International evidence $[\mathrm{J}]$. Journal of International Financial Market, 2017, 9(12), pp.112-147.

[7] Andrew M., Sam A. A., Frank S. Realism, skill, and incentives: Current and future trends in investment management and investment performance $[\mathrm{J}]$. International Review of Financial Analysis, 2016, 43, pp. 31-40.

[8] Zhu Y. J. Study on Optimization of Investment Allocation in Power Grid Based on Regional Development[J]. Electric Power \& Energy, 2016, (6), pp.704-708

[9] Chen F., Hope O., li Q. and Wang X. Financial Reporting Quality and Investment Efficiency of Private Firms in Emerging Markets [J]. The Accounting Review, 2011, (86) pp. 1255-1288. 